\title{
Assessment of Heavy Metal Pollution in Soil and Sediments of Murgul Copper Mine and Its Surroundings
}

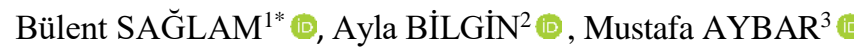 \\ ${ }^{1}$ Artvin Çoruh University, Faculty of Forestry, Department of Forest Engineering, Artvin, TURKEY \\ ${ }^{2}$ Artvin Çoruh University, Faculty of Engineering, Department of Environmental Engineering, Artvin, \\ TURKEY \\ ${ }^{3}$ Artvin Çoruh University, Artvin Vocational High School, Artvin, TURKEY \\ *Corresponding Author: bsaglam@artvin.edu.tr
}

Received Date: 31.12.2019

Accepted Date: 10.02 .2020

\begin{abstract}
Aim of study: This study focuses on the changes of heavy metal pollution in soil and sediment.

Study area: The study area covers Murgul district of Artvin located over the Eastern Black Sea region, Turkey.

Material and method: Sampling areas were determined at distances in the direction of surface flow along the stream route where waste water was discharged by assuming the Copper Plant as the central point. A total of 54 soil and 10 sediment samples were taken from sampling points.

Main results: The results of analysis of soil and sediment samples indicated that the mean values of Copper, Lead and Zinc were remarkably higher than the threshold values and the soil $\mathrm{pH}$ decreased as it moved away from the center point. The contaminated sediments, deposited over the years in the river bank sediments may act as secondary source of pollution to the covering water column in the river.

Research highlights: Heavy metals from the soil during the rehabilitation activities to be applied in the mining sites, it is suggested to investigate the phytoremediation techniques, which are very successful and effective methods both economically and ecologically, and to use appropriate plant species in the rehabilitation areas.
\end{abstract}

Keywords: Heavy Metal Pollution, Mining, Murgul, Sediment, Soil

\section{Murgul Bakır Madeni ve Çevresindeki Toprak ve Sedimentlerde Meydana Gelen Ağır Metal Kirliliğinin Değerlendirilmesi}

$\ddot{O} \mathbf{z}$

Çalışmanın amacı: Bu çalışmada; toprak ve sedimentteki ağır metal kirliliğinin mesafeye bağlı olarak değişimi ortaya konulmaya çalışılmıştır.

Çalışma alanı: Türkiye'nin Doğu Karadeniz Bölgesinde yer alan Artvin İli, Murgul İlçesi sınırları içerisinde yer alan bakır işletmesi ve güzergâhını kapsamaktadır.

Materyal ve yöntem: Örnek alanlar, merkez noktası bakır işletmesi kabul edilerek atık suyun boşaltıldığı dere güzergâhı boyunca yüzeysel akış yönünde belirlenmiştir. Örneklemede toplamda 0-10 ve $10-20 \mathrm{~cm}$ derinlik kademelerinden 54 adet toprak ve $0-10 \mathrm{~cm}$ derinlik kademesinden ise 10 adet sediment örneği alınmıştır.

Temel sonuçlar: Toprak ve sediment örneklerinin ağır metal analiz sonuçlarına bakıldığında özellikle kirletici kaynağa yakın alanlarda Bakır, Kurşun ve Çinko değerlerinin ortalamaları sınır değerlerin çok üzerinde olduğu ve merkez noktadan uzaklaş̧ıkça toprak asitliğinin azaldı̆̆ı tespit edilmiştir.

Araştırma vurguları: Maden sahalarında yapılacak rehabilitasyon çalışmalarında ağır metallerin topraktan giderilmesine katkı yapmak üzere, hem ekonomik hem de ekolojik bakımdan oldukça başarılı ve etkin bir yöntem olan fitoremediasyon tekniklerinin araştırılması ve uygun bitki türlerinin belirlenerek kullanılması önerilmektedir..

Anahtar Kelimeler: Ağır Metal Kirliliği, Madencilik, Murgul, Sediment, Toprak

\section{Introduction}

Soil in constant contact and interaction with external factors, gains physical and chemical differences with many ecological factors such as water, air, light, temperature and humidity. Under normal conditions, there is a natural balance among the basic environmental elements such as air, water 
and soil. There would be no apparent problems with the vitality and maintenance of the environment, unless this balance is severely disrupted. However, any problem or complication occurring in one of these elements triggers the other element subsequently and causes the natural balance to be disturbed. Overpopulation, local soil erosion, mining activities, careless disposal of industrial waste and intensive deforestation have badly affected the quality of the river water. Thus, external chemicals that are not naturally present in an environmental and substances that are naturally present in the environment but whose concentrations exceed the required level are considered as pollutants (Korkmaz \& Kizilkaya, 1998).

Heavy metal ions are the leading causes of environmental pollution. Increasing household wastes as a result of proliferation of urban population, various industrial and chemical wastes from developing industrial enterprises, pollutants from mining enterprises, artificial fertilizers with metal contents, pesticides, herbicides, fungicides and other fertilizers used in agriculture have long caused heavy metal accumulation in soil, ground and surface water bodies.

Soil pollution is one of the biggest environmental problems around the world happening with respect to the advancement of technological and industrial developments. Soil pollution is defined as the intrusion of various compounds generated as a result of human activities to the soil, the decrease in yield due to the excess intrusion of those compounds above the soil's absorbing capacity or the presence of these compounds at a level that will harm or poison the living organisms (Anonymous, 2005).

Heavy metal pollution is one of the most serious environmental problems pending for solution around the world. The dissemination of heavy metals in sediments may provide researchers with evidence of human impact on aquatic ecosystems in assessing the risks associated with discharged human waste. Since heavy metal pollution increases with respect to the increase in industrialization, the balance of natural biological cycles is also negatively affected. Heavy metals in the soil cause the arthropods (Duyar, 2019) and the microorganisms in the soil and reduce their number and biological activities over time (Khan et al., 2010).

Another factor affected by the heavy metal ions is sediment. The sediment creating the riverbed is in a constant contact with the water body, a large reservoir for metals in the aquatic environment and holds more than $99 \%$ of the metals in the environment (Bagheri et al., 2011). Increased levels of heavy metals in sediment cause them to recur and infiltrate from sediment to water and cause toxic effects on aquatic organisms. Therefore, sediment emerges as a separate pollutant source (Macdonald et al., 2000, Rauf et al., 2009). As such, sediment has gained attention in studies concentrating on the determination of environmental pollution levels of heavy metals and many researchers have focused on this issue (Macdonald et al., 2000, Olivares-Rieumont et al., 2005, Begum et al., 2009, Akbulut \& Tuncer, 2011, Alp et al., 2012)

Heavy metals are released to the environment in two different ways: anthropogenic and natural disturbances. Erosion of minerals with air and wind circulation, soil erosion and volcanic eruptions are the most important factors originating from natural disturbances. On the other hand, anthropogenic originated causes or disturbances can be listed as mining, thermal power plants, domestic heating systems, motor vehicles, fertilizers, pesticides, iron-steel, sugar, cement, petrochemical and metal industries (Chehregani \& Malayeri, 2007; SabihaJavied et al., 2009). The main reason for the presence of heavy metals in the ecological system and their distribution in natural resources is not the natural cycles, but rather the industrial effects originating from human causes or disturbances.

Heavy metals have severe adverse effects on both plants and animals in the forest ecosystem, as well as on all species and human health interacting with the forest. They may exhibit different symptoms in the human body depending on the structure of the metal ion, its solubility value, chemical structure, ability to form redox and complex, its ingestion mechanism to body, and the 
frequency of its presence in the environment (Özbolat \& Tuli, 2016). According to various scientific studies, significant relationships were found in the blood-heavy metal levels in various cancer types (mainly head and neck cancer) (Gözdaşoğlu et al., 1989; Kohli et al., 1989; Kanat, 2005; Bilici, 2005; Seven, 2010). Identification as well as treatment of contaminated sediments may be as important as the treatment of sewage sludge to overcome the health problems. Therefore, this study aims to examine and analyze heavy metal pollution in both soil and sediments created by mining activities. Furthermore, this research also focuses on raising awareness about identifying the possible damages to the environment beforehand, taking necessary measures and minimizing the possible damages during the production process in an industrial field.

\section{Materials and Methods}

The case study area covers Murgul district of Artvin located over the Eastern Black Sea region, Turkey. Specifically, the case study area starts from the center of Murgul Copper Plant and extents along the path of the stream where waste water is discharged. Some areas of the stream route, which constitute the research area, include some private lands. However, most of the case study area is within the boundaries of Borçka State Forest Industry (Figure 1).

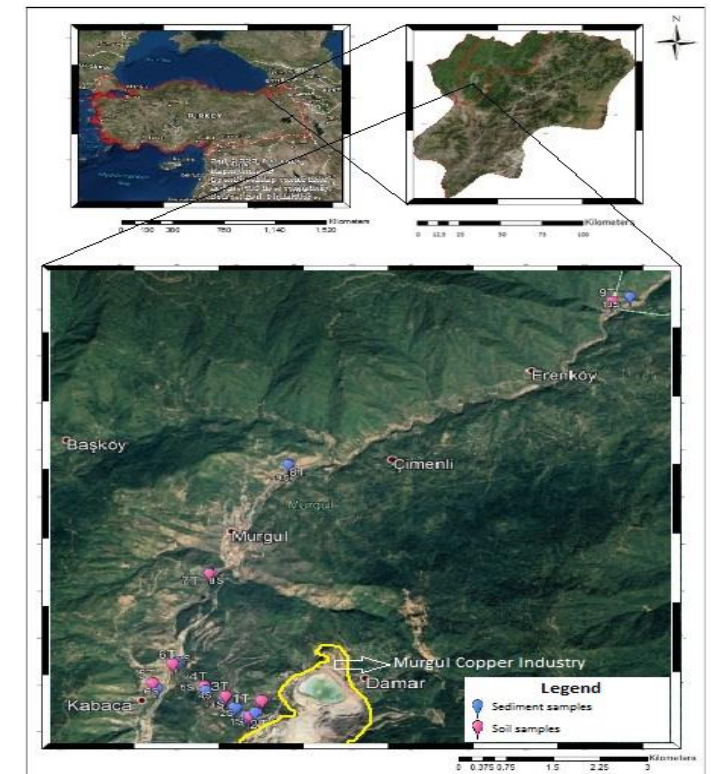

Figure 1. Case study area and the locations of soil and sediment sample points

The samples were taken from each site on fortnightly basis. Each sampling station was divided into three sub-sampling areas. Three different soil samples were taken to represent each area ensuring that the determined sample points are within $100 \mathrm{~m}^{2}$ of area. The coordinates of the samples were given in Table 1.

Within the scope of the study, sampling areas were determined at 100, 250, 750, $1000,1500,2000,3000,5000$ and $10000 \mathrm{~m}$ distances in the direction of surface flow along the stream route where waste water was discharged by assuming the Copper Plant as the central point. Three different sampling points were taken in each of the 9 sampling stations by random sampling method within $100 \mathrm{~m}^{2}$ area in order to determine soil reaction and heavy metal contamination. A total of 54 soil samples were taken from $0-10$ and $10-20 \mathrm{~cm}$ depth levels and 10 sediment samples from 0-10 $\mathrm{cm}$ depth levels. SPSS 15.0 TM data analysis software was used for numerical data analysis and ArcGIS 9.3 тм was used for processing and analysis of geographic data.

In order to represent the case study area, the soil samples were taken from $0-10 \mathrm{~cm}$ and 10-20 cm depth levels with approximately $1-1,5 \mathrm{~kg}$ in weight. The sediment samples were also taken from a depth of $0-10 \mathrm{~cm}$ to represent the case study 
areas with approximately $1-1.5 \mathrm{~kg}$ in weight (Jackson, 1967). The samples collected from three sub-sampling points at each station were homogenized to obtain a composite sample. Both soil and sediment samples taken from the field were first laid in drying cabinets in the laboratory in order to prepare them for analysis. Air-dried soils were properly grounded in mortar and put into polyethylene bags (Chapman et al., 1961).

Reactions $(\mathrm{pH})$ of sediment and soil samples were determined by glass electrode method using Inolab $\mathrm{pH}$ meter. Analysis of the actual acidity $1 / 2.5$ soil-water mixture was determined by measuring after standing overnight (Gülçur, 1974).
The concentration of elements such as Chromium (Cr), Manganese (Mn), Nickel $(\mathrm{Ni})$, Copper $(\mathrm{Cu})$, Zinc $(\mathrm{Zn})$ and Lead $(\mathrm{Pb})$ were determined using microwave acid lysis method (EPA $3052 \mathrm{~A}$ ) in the ICP-OES instrument during the analysis of heavy metals in sediment and soil samples. The calibration curves of all compounds were plotted based on linear regression analysis of corresponding intensity (X, milivolt) versus concentrations. Regression equation and correlation coefficient of three markers were determined for linearity $\left(R^{2}>0.99\right)$ for all metal standards performed three replicates of each

test.

Table 1. Coordinates of soil sample points

\begin{tabular}{ccccccccc}
\hline $\begin{array}{c}\text { Sample } \\
\text { Code }\end{array}$ & $\begin{array}{c}\mathrm{X} \\
\text { Coordinate }\end{array}$ & $\begin{array}{c}\text { Y } \\
\text { Coordinate }\end{array}$ & $\begin{array}{c}\text { Sample } \\
\text { Code }\end{array}$ & $\begin{array}{c}\text { X } \\
\text { Coordinate }\end{array}$ & $\begin{array}{c}\text { Y } \\
\text { Coordinate }\end{array}$ & $\begin{array}{c}\text { Sample } \\
\text { Code }\end{array}$ & $\begin{array}{c}\text { X } \\
\text { Coordinate }\end{array}$ & $\begin{array}{c}\text { Y } \\
\text { Coordinate }\end{array}$ \\
\hline 1A & 715454 & 4569438 & 4A & 714655 & 4569538 & $7 \mathrm{~A}$ & 714370 & 4571800 \\
\hline 1B & 715447 & 4569441 & 4B & 714602 & 4569556 & $7 \mathrm{~B}$ & 714350 & 4571781 \\
\hline 1C & 715450 & 4569470 & 4C & 714573 & 4569580 & $7 \mathrm{C}$ & 714359 & 4571825 \\
\hline 2A & 715367 & 4569159 & 5A & 714054 & 4570075 & $8 \mathrm{~A}$ & 715393 & 4574050 \\
\hline 2B & 715340 & 4569165 & 5B & 714036 & 4570072 & $8 \mathrm{~B}$ & 715380 & 4574035 \\
\hline 2C & 715375 & 4569149 & 5C & 714010 & 4570058 & $8 \mathrm{C}$ & 715404 & 4574056 \\
\hline 3A & 714847 & 4569439 & 6A & 713700 & 4569640 & 9A & 720340 & 4577747 \\
\hline 3B & 714878 & 4569460 & 6B & 713722 & 4569650 & 9B & 720324 & 4577742 \\
\hline 3C & 714812 & 4569477 & 6C & 713730 & 4569672 & 9C & 720320 & 4577760 \\
\hline
\end{tabular}

\section{Results}

Statistical analysis was performed to evaluate the measurement results. ANOVA analysis was conducted to determine the difference between the measurement points, hierarchical analysis was performed to organize the data into groups and factor analysis was performed to determine the important parameters between the data.

Specifically, heavy metal analyzes were performed to determine the contents of $\mathrm{Cr}$, $\mathrm{Mn}, \mathrm{Ni}, \mathrm{Cu}, \mathrm{Zn}$ and $\mathrm{Pb}$ of 54 soil samples and 10 sediment samples, taken from 9 different distances to the pollutant source. The numerical results are given in Tables 3 and 4. When the results of heavy metal analysis of soil samples are examined, it can be seen that $\mathrm{Cu}, \mathrm{Mn}, \mathrm{Pb}$ and $\mathrm{Zn}$ values are above the threshold values especially in areas close to the pollutant source (Adagunodo at al., 2018). According to the results of analysis, it was determined statistically that the $\mathrm{Cr}, \mathrm{Pb}$ and $\mathrm{Zn}$ values increased depending on the distance to the pollutant source. Depending on the heavy metal concentrations obtained in the analysis, the results were compared with the world threshold values (Okereafor at al., 2019, G. Toth at al., 2016, UNEP 2013, De Astudillo at al., 2005) and soil samples $\mathrm{Cu}$ and $\mathrm{Pb}$. It was observed that the average of $\mathrm{Cu}, \mathrm{Pb}$ and $\mathrm{Zn}$ from the sediment samples were above the threshold values (Table 2). 
Table 2. Threshold and permissible limits for heavy metals in soils and USEPA Guidelines for sediments

\begin{tabular}{l|ccc|cccc}
\hline \multirow{2}{*}{$\begin{array}{l}\text { Heavy } \\
\text { Metals }\end{array}$} & \multicolumn{3}{|c|}{ Heavy Metals in Soils (ppm) } & \multicolumn{4}{c}{ Heavy Metals in Sediments (ppm) } \\
\cline { 2 - 8 } & \multicolumn{2}{|c}{ Threshold Permissible } & $\begin{array}{c}\text { Current } \\
\text { Study }\end{array}$ & $\begin{array}{c}\text { Not } \\
\text { polluted }\end{array}$ & $\begin{array}{c}\text { Moderately } \\
\text { polluted }\end{array}$ & $\begin{array}{c}\text { Heavily } \\
\text { polluted }\end{array}$ & $\begin{array}{c}\text { Current } \\
\text { Study }\end{array}$ \\
\hline $\mathrm{Cu}$ & 100 & $50^{*}$ & 337 & $<25$ & $25-50$ & $>50$ & 3850 \\
\hline $\mathrm{Pb}$ & 60 & $200^{* *}$ & 174 & $<40$ & $40-60$ & $>60$ & 2985 \\
\hline $\mathrm{Zn}$ & 200 & $250^{*}$ & 157 & $<90$ & $90-200$ & $>200$ & 1010 \\
\hline $\mathrm{Ni}$ & 50 & $100^{*}$ & 15 & $<21$ & $21-50$ & $>50$ & 3 \\
\hline $\mathrm{Cr}$ & 100 & $200^{*}$ & 14 & $<25$ & $25-75$ & $>75$ & 2 \\
\hline
\end{tabular}

Note: The risk associated with higher concentrations than the permissible limits are grouped into $\begin{array}{llllll}\text { ecological risk } & (*) & \text { and } & \text { health }\end{array}$

The soil $\mathrm{pH}$ analysis results for soil and sediment samples are shown in Figures 2 and 3. As indicated in Figures 2 and 3, the $\mathrm{pH}$ values increase as it is moved away from the source of contaminants, i.e., the acidity decreases. Heavy metals are highly soluble in acidic environments. The high acidity at points close to the mine site indicates that the pollution is high.

Table 3. Mean heavy metal concentrations of soil samples according to sample points and depth levels

\begin{tabular}{|c|c|c|c|c|c|c|}
\hline Distance (m) & \multirow{2}{*}{\multicolumn{2}{|c|}{$\frac{100 \mathrm{~m}}{1 \mathrm{st} \text { point }}$}} & \multicolumn{2}{|c|}{$250 \mathrm{~m}$} & \multicolumn{2}{|c|}{$750 \mathrm{~m}$} \\
\hline Sample No & & & & bint & & bint \\
\hline Depth $(\mathrm{cm})$ & $0-10$ & $10-20$ & $0-10$ & $10-20$ & $0-10$ & $10-20$ \\
\hline $\mathrm{Cr}(\mathrm{mg} / \mathrm{kg})$ & 12.92 & 12.92 & 15.58 & 13.33 & 12.83 & 15.08 \\
\hline $\mathrm{Cu}(\mathrm{mg} / \mathrm{kg})$ & 455.58 & 454.50 & 468.25 & 461.17 & 517.58 & 569.50 \\
\hline Mn (mg/kg) & 404.25 & 800.67 & 1153.58 & 972.67 & 878.00 & 305.75 \\
\hline $\mathrm{Ni}(\mathrm{mg} / \mathrm{kg})$ & 13.17 & $<18$ & 14.75 & 13.83 & 11.24 & 28.83 \\
\hline $\mathrm{Pb}(\mathrm{mg} / \mathrm{kg})$ & 223.17 & 218.17 & 212.17 & 203.17 & 242.75 & 294.83 \\
\hline $\mathrm{Zn}(\mathrm{mg} / \mathrm{kg})$ & 134.17 & 119.58 & 85.08 & 98.75 & 94.50 & 182.83 \\
\hline Distance (m) & \multicolumn{2}{|c|}{$1000 \mathrm{~m}$} & \multicolumn{2}{|c|}{$1500 \mathrm{~m}$} & \multicolumn{2}{|c|}{$2000 \mathrm{~m}$} \\
\hline Sample No & \multicolumn{2}{|c|}{ 4th point } & \multicolumn{2}{|c|}{ 5th point } & \multicolumn{2}{|c|}{ 6th point } \\
\hline Depth $(\mathrm{cm})$ & $0-10$ & $10-20$ & $0-10$ & $10-20$ & $0-10$ & $10-20$ \\
\hline $\mathrm{Cr}(\mathrm{mg} / \mathrm{kg})$ & $<1$ & $<1$ & 13.75 & 12.83333 & 12.67 & 12.92 \\
\hline $\mathrm{Cu}(\mathrm{mg} / \mathrm{kg})$ & 196.50 & 152.42 & 675.33 & 166.1667 & 59.00 & 51.50 \\
\hline Mn (mg/kg) & 677.17 & 342.00 & 682.75 & 903.5 & 712.83 & 740.17 \\
\hline $\mathrm{Ni}(\mathrm{mg} / \mathrm{kg})$ & 12.08 & 10.92 & $<1$ & $<1$ & 13.25 & 12.67 \\
\hline $\mathrm{Pb}(\mathrm{mg} / \mathrm{kg})$ & 107.08 & 82.33 & 361.00 & 85.25 & 29.92 & 28.33 \\
\hline $\mathrm{Zn}(\mathrm{mg} / \mathrm{kg})$ & 112.08 & 97.58 & 276.42 & 85.75 & 66.08 & 70.67 \\
\hline Distance (m) & \multicolumn{2}{|c|}{$3000 \mathrm{~m}$} & \multicolumn{2}{|c|}{$5000 \mathrm{~m}$} & \multicolumn{2}{|c|}{$10000 \mathrm{~m}$} \\
\hline Sample No & \multicolumn{2}{|c|}{ 7th point } & \multicolumn{2}{|c|}{ 8th point } & \multicolumn{2}{|c|}{ 9th point } \\
\hline Depth $(\mathrm{cm})$ & $0-10$ & $10-20$ & $0-10$ & $0-10$ & $10-20$ & $0-10$ \\
\hline $\mathrm{Cr}(\mathrm{mg} / \mathrm{kg})$ & 14.50 & 15.17 & 22.92 & 18.33 & 16.08 & 14.25 \\
\hline $\mathrm{Cu}(\mathrm{mg} / \mathrm{kg})$ & 188.00 & 233.25 & 685.58 & 565.58 & 95.67 & 84.75 \\
\hline $\mathrm{Mn}(\mathrm{mg} / \mathrm{kg})$ & 549.33 & 595.83 & 784.42 & 804.08 & 816.92 & 818.75 \\
\hline $\mathrm{Ni}(\mathrm{mg} / \mathrm{kg})$ & 16.17 & 16.42 & 26.25 & 20.58 & 16.58 & 13.58 \\
\hline $\mathrm{Pb}(\mathrm{mg} / \mathrm{kg})$ & 125.50 & 153.50 & 344.75 & 335.17 & 52.17 & 47.92 \\
\hline $\mathrm{Zn}(\mathrm{mg} / \mathrm{kg})$ & 133.42 & 151.17 & 590.67 & 318.75 & 90.67 & 126.92 \\
\hline
\end{tabular}


Table 4. Heavy metal concentration of sediment samples

\begin{tabular}{lccccc}
\hline Sample No & 1st point & 2nd point & 3rd point & 4th point & 5th point \\
\hline Distance & $100 \mathrm{~m}$ & $250 \mathrm{~m}$ & $500 \mathrm{~m}$ & $750 \mathrm{~m}$ & $1000 \mathrm{~m}$ \\
\hline $\mathrm{Cr}(\mathrm{mg} / \mathrm{kg})$ & $<1$ & $<1$ & $<1$ & $<1$ & $<1$ \\
\hline $\mathrm{Cu}(\mathrm{mg} / \mathrm{kg})$ & 6882.5 & 13065 & 5707.5 & 6907.5 & 468 \\
\hline $\mathrm{Mn}(\mathrm{mg} / \mathrm{kg})$ & 182 & 128.75 & 162.5 & 169.25 & 519 \\
\hline $\mathrm{Ni}(\mathrm{mg} / \mathrm{kg})$ & $<1$ & $<1$ & $<1$ & $<1$ & $<1$ \\
\hline $\mathrm{Pb}(\mathrm{mg} / \mathrm{kg})$ & 6658.5 & 5750 & 10762.25 & 3827.75 & 227 \\
\hline $\mathrm{Zn}(\mathrm{mg} / \mathrm{kg})$ & 1785.75 & 3455 & 1141.5 & 1414.75 & 438.5 \\
\hline $\mathrm{Sample} \mathrm{No}$ & 6 th point & 7 th point & 8 th point & 9 th point & 10 point \\
\hline $\mathrm{Distance}$ & $1500 \mathrm{~m}$ & $2000 \mathrm{~m}$ & $3000 \mathrm{~m}$ & $5000 \mathrm{~m}$ & $10000 \mathrm{~m}$ \\
\hline $\mathrm{Cr}(\mathrm{mg} / \mathrm{kg})$ & $<1$ & $<1$ & $<1$ & $<1$ & 13.75 \\
\hline $\mathrm{Cu}(\mathrm{mg} / \mathrm{kg})$ & 3707.5 & 433.25 & 432.25 & 447.5 & 450.25 \\
\hline $\mathrm{Mn}(\mathrm{mg} / \mathrm{kg})$ & 497.75 & 500.5 & 497 & 694.25 & 686 \\
\hline $\mathrm{Ni}(\mathrm{mg} / \mathrm{kg})$ & $<1$ & $<1$ & $<1$ & 13 & 16.5 \\
\hline $\mathrm{Pb}(\mathrm{mg} / \mathrm{kg})$ & 1645 & 227 & 247.25 & 267.25 & 242.25 \\
\hline $\mathrm{Zn}(\mathrm{mg} / \mathrm{kg})$ & 717.25 & 165.5 & 342 & 282 & 363 \\
\hline
\end{tabular}

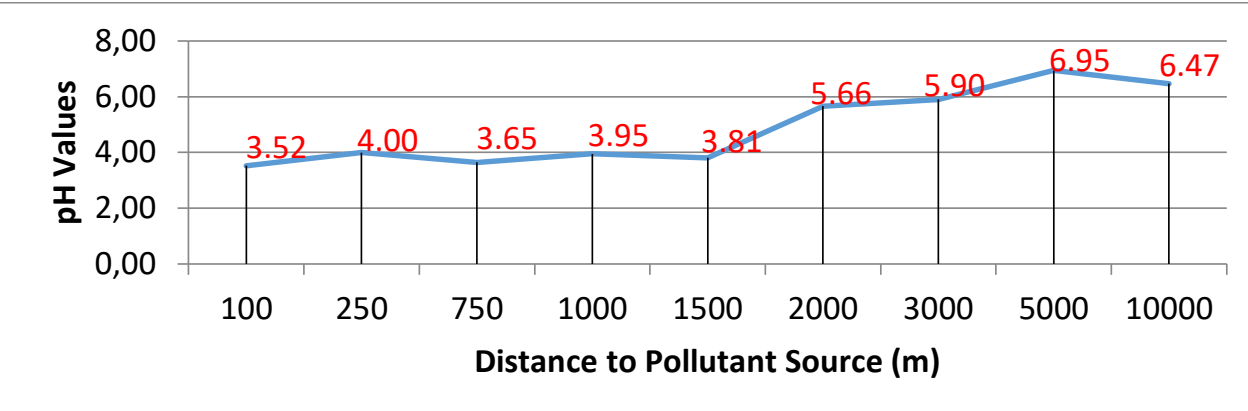

Figure 2. Change of $\mathrm{pH}$ values for soil samples as they move away from the source of pollutants

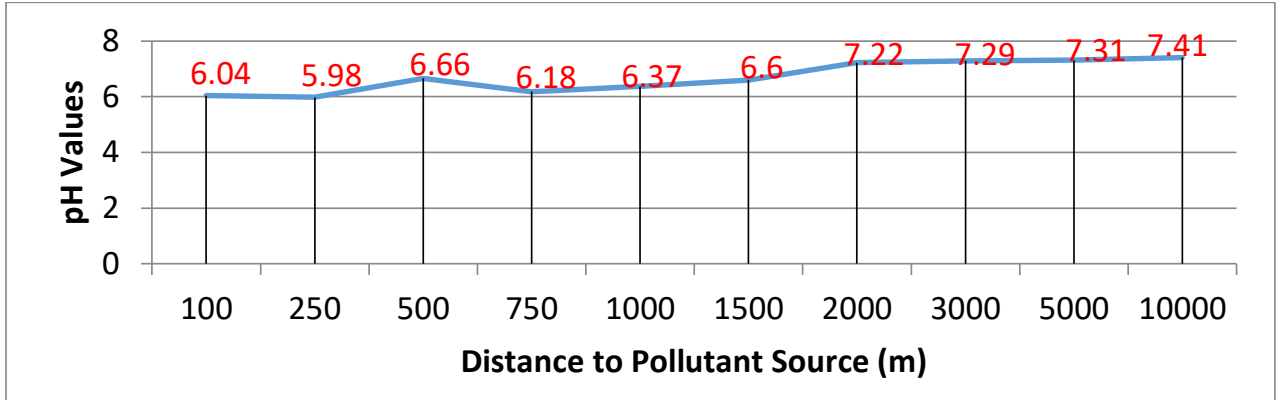

Figure 3. Change of $\mathrm{pH}$ values for sediment samples as they move away from the source of pollutants

\section{Statistical Analysis of Soil Samples}

ANOVA Analysis

ANOVA analysis is used to test whether the means of more than two independent groups are different from each other. As a result of sampling analysis. one-way analysis of variance was performed to determine the difference depending on distance and depth (Table 5). In the one-way analysis of variance. $\mathrm{Cr}, \mathrm{Pb}$ and $\mathrm{Zn}$ values were found to be statistically different $(\mathrm{p}<0.05)$ depending on distances. 
Table 5. The changes of heavy metal concentration depending on the distances

\begin{tabular}{|c|c|c|c|c|c|c|}
\hline & & $\begin{array}{l}\text { Sum of } \\
\text { Squares }\end{array}$ & $\mathrm{df}$ & $\begin{array}{l}\text { Mean } \\
\text { Square }\end{array}$ & $\mathrm{F}$ & Sig. \\
\hline \multirow{3}{*}{$\mathrm{Cr}$} & $\begin{array}{l}\text { Between } \\
\text { Groups }\end{array}$ & 295.509 & 8 & 36.939 & 7.167 & 0 \\
\hline & $\begin{array}{l}\text { Within } \\
\text { Groups }\end{array}$ & 231.927 & 45 & 5.154 & & \\
\hline & Total & 527.436 & 53 & & & \\
\hline \multirow{3}{*}{$\mathrm{Pb}$} & $\begin{array}{l}\text { Between } \\
\text { Group }\end{array}$ & 516465.48 & 8 & 64.558 .184 & 2.295 & 0.037 \\
\hline & $\begin{array}{l}\text { Within } \\
\text { Groups }\end{array}$ & 1265633.4 & 45 & 28.125 .188 & & \\
\hline & Total & 1782098.9 & 53 & & & \\
\hline \multirow{3}{*}{$\mathrm{Zn}$} & $\begin{array}{l}\text { Between } \\
\text { Groups }\end{array}$ & 646821.38 & 8 & 80.852 .673 & 3.275 & 0.005 \\
\hline & $\begin{array}{l}\text { Within } \\
\text { Groups }\end{array}$ & 1110915.2 & 45 & 24.687 .004 & & \\
\hline & Total & 1757736.6 & 53 & & & \\
\hline
\end{tabular}

One-way analysis of variance conducted on the depth of soil samples taken from each point along various distances indicated that there was no statistically significant difference. For soil reaction samples, there was a significant difference between the measurement points depending on the distance (Table 6). ANOVA analysis shows that contamination is observed by the surface runoff. This happens depending on the geographical conditions.

Table 6. Changes of $\mathrm{pH}$ values depending on distances

\begin{tabular}{lccccc}
\hline $\mathrm{pH}$ & $\begin{array}{c}\text { Sum of } \\
\text { Squares }\end{array}$ & $\mathrm{df}$ & $\begin{array}{c}\text { Mean } \\
\text { Square }\end{array}$ & $\mathrm{F}$ & Sig. \\
\hline Between Groups & 81.928 & 8 & 10.241 & 13.361 & 0 \\
\hline Within Groups & 34.492 & 45 & 0.766 & & \\
\hline Total & 116.419 & 53 & & & \\
\hline
\end{tabular}

\section{BOX-PLOT Graphic}

The box plot graph is designed to identify the differences between the measurement points and summarizes the quantitative data visually. The line above the box represents the median. The points at the bottom and top of the box indicate the first and third quarters (Q1 and Q3). The highest and lowest observation values within the Whiskers region are shown as the line extending to the bottom and top points of the box. Boxwhisker graphs were drawn for soil samples. According to the data obtained in the graph, the range of $\mathrm{Cu}, \mathrm{Pb}$ and $\mathrm{Mn}$ in the first 100 750 and 5000 meter distances was high (Figure 4). The graphs show that heavy metal deposits are high at points close to the mine site. 

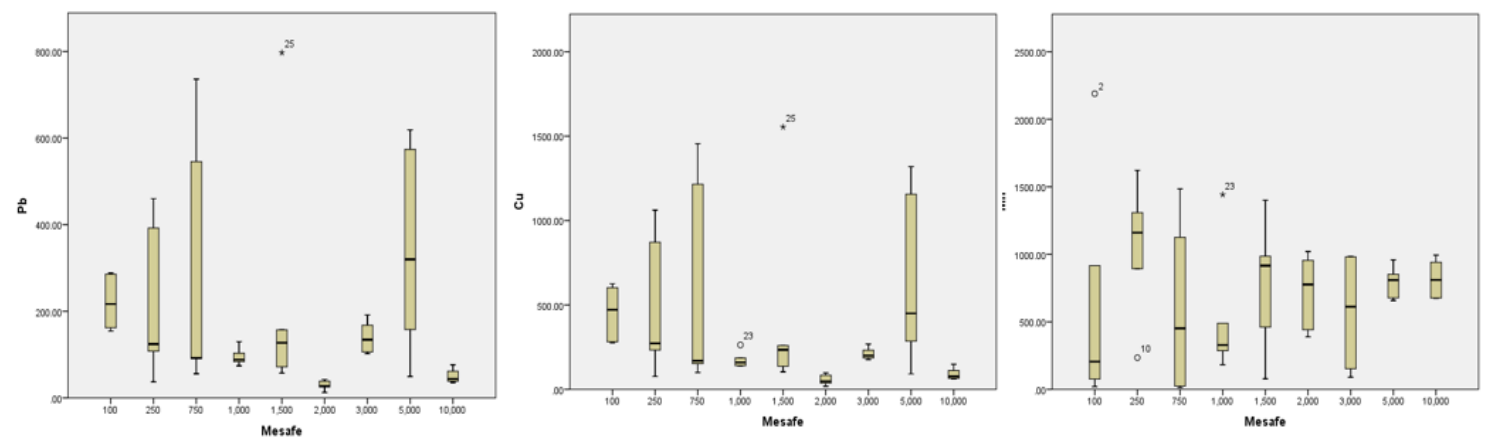

Figure 4. Box-plot graphs for soil samples

Cluster

Cluster analysis generate groupings of soil samples by examining their similarities in chemical composition (Shreatha \& Kazama, 2007). Wards method was used to classify the samples in agglomerative hierarchical clustering analysis where the criterion for choosing the pair of clusters to merge at each step is based on the optimal value of an objective function. Specifically, this method has a feature of merging less observed clusters.

Clustering analysis for soil samples yielded three groups. In the first group, sample points at $100-1500 \mathrm{~m}$ distances showed similarities to each other. In the second group, sample points at 1000-10000
Analysis $\mathrm{m}$ distances also showed similarities to each other. In the third and last group, however, the 8th point located at $5000 \mathrm{~m}$ distance from the pollutant center is separated from the others (Figure 5). The pollution status of the sampled points is grouped using cluster analysis. The grouping in this way also shows that there is a change in pollution depending on the distance.

The first group refers to the area of high pollution while the second group can be named as a low pollution area. It is estimated that the reason of pollution at point 8 , which is the third group at $5000 \mathrm{~m}$ distance, was caused by the use of the mining factory as a rust casting site until 12 years ago.

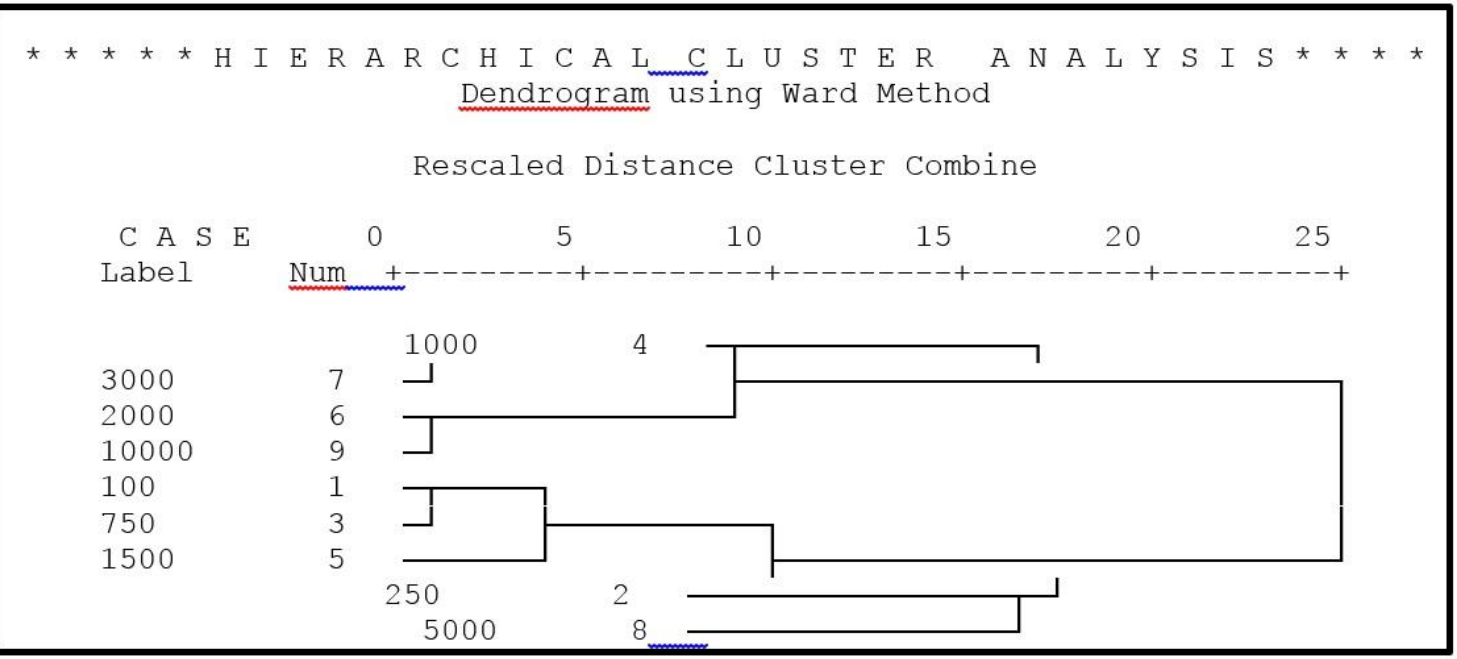

Figure 5. Distance-dependent clustering analysis graph for soil samples

\section{Statistical Analysis of Sediment Samples} Factor Analysis

Factor analysis was assessed according to Kaires- Meyer-Olkin (KMO) and Bartlett's Test results. KMO value was 0.605 and
Bartlett's Test value was 0.000. Since the KMO value is greater than 0.5 and Bartlett's test value is less than 0.05 , the tests can be suitable for this data. Two factors with eigenvalue $>1$ and a decreasing ratio of each 
one to total variance were determined as a result of Factor Analysis. According to the result of Varimax rotation method, there are 2 factors with eigenvalue $>1$. These two factors explain $85.4 \%$ of the total variance. The first factor explained $53.67 \%$ of the total variance, $\mathrm{Cu}(0.971), \mathrm{Pb}(0.717)$ and $\mathrm{Zn}$ (0.976) had a high positive charge and Mn (0.815 ) had a high negative charge value. The second factor explained $31.7 \%$ of the total variance and $\mathrm{Cr}(0.974)$ and $\mathrm{Ni}(0.976)$ had high positive charge values (Table 7 ). The fact that copper is an important pollutant as a result of factor analysis is due to copper mining. The elements $\mathrm{Cu}, \mathrm{Zn}$ and $\mathrm{Pb}$ are often associated with sulfur minerals.

Table 7. Factor analysis values for sediment samples

\begin{tabular}{lcc}
\hline Component & & \\
\hline & 1 & 2 \\
\hline $\mathrm{Cr}$ & -0.109 & 0.974 \\
\hline $\mathrm{Cu}$ & 0.971 & -0.173 \\
\hline $\mathrm{Mn}$ & -0.815 & 0.440 \\
\hline $\mathrm{Ni}$ & -0.150 & 0.976 \\
\hline $\mathrm{Pb}$ & 0.717 & -0.287 \\
\hline $\mathrm{Zn}$ & 0.976 & -0.091 \\
\hline Extraction Method: & Principal & Component Analysis. \\
Rotation Method: Varimax with Kaiser Normalization.
\end{tabular}

\section{Cluster Analysis}

Cluster analysis of sediment samples yielded two groups. The first group with the sample points in 100-750 m was found to be similar to each other. This group was considered as the point where the pollution is high. The second group was formed as a result of the analysis showing similarities between sediment samples at 1000-10000 m distances. The second group was considered to be consisted of the samples points with less pollution (Figure 6). These results support the result of cluster analysis for soil analysis.

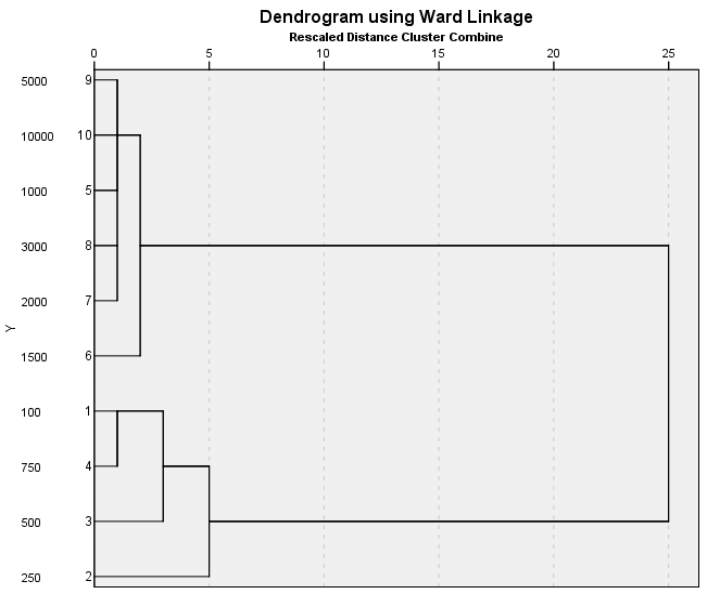

Figure 6. Distance-dependent clustering analysis for sediment samples

\section{Discussion and Conclusion}

Heavy metal pollution in soil has emerged as a significant environmental problem as a result of industrial developments and increasing mining activities. Heavy metal ions are among the most harmful soil pollutants. Unlike organic pollutants in the soil, they continue to create environmental pollution for a long time as they cannot be removed from the ecosystem as they are toxic and cannot be chemically or biologically degraded.

In this study, heavy metal pollution as a result of mining activities was investigated. According to the results of the research, the following points can be highlighted;

One-way analysis of variance for soil samples indicated that $\mathrm{Cr}, \mathrm{Pb}$ and $\mathrm{Zn}$ values were statistically different ( $p \quad<0.05)$ depending on distances. However, it was found that there was no statistical difference when the depth of soil was considered.

In a thesis study conducted in Northern Iraq (Ahmad, 2017), the heavy metal contents of soil samples taken at 200, 2000 and $10000 \mathrm{~m}$ distances from the industrial zone decreased as it was moved away from the mining site. In a different study to investigate the accumulation of heavy metal pollution of traffic origin in Poland in plants and soils, the $\mathrm{Pb}, \mathrm{Ni}$ and $\mathrm{Mn}$ concentrations of samples taken from the regions far from the city and from the regions close to the city center were compared to each other. The results indicated that the heavy metal pollution level in the regions close to the city 
center is much higher than that of the region far from the center (Knezevic et. al., 2009). Thus, the results from both studies are in accordance with our results.

Cluster analysis for soil samples yielded three groups. In the first group, sample points at $100-1500 \mathrm{~m}$ distances showed similarities to each other. In the second group, sample points at 1000-10000 $\mathrm{m}$ distances also showed similarities to each other. In the third and last group, however, the 8th point located at $5000 \mathrm{~m}$ distance from the pollutant center is separated from the others. The first group is of an area with high pollution while the second group can be called as a low pollution area. When the reason of pollution at point 8 , which is the third group at $5000 \mathrm{~m}$ distance, was investigated, it was determined that the mining factory was used as a rust casting site until 12 years ago. Therefore, heavy metal contents are thought to be high. Besides, in other sample areas, the heavy metal contents were observed to decrease depending on the distances. However, the high values of $\mathrm{Cu}, \mathrm{Pb}$ and $\mathrm{Zn}$ contents in this area indicate that heavy metals accumulated in the area used as a rust casting area for a long time are still present. When the results of a similar study conducted in the industrial zone of İzmir Aliağa were examined, it was observed that there was a serious soil pollution in the nearby regions of the factories and the pollution values decreased as they moved away from the industrial area (Kale, 2014).

As a result of factor analysis for sediment samples, two factors were observed significant, explaining $85.4 \%$ of total variance. The first factor explained $53.6 \%$ of the total variance. $\mathrm{Cu}, \mathrm{Pb}$ and $\mathrm{Zn}$ had a strong positive charge and $\mathrm{Mn}$ had a high negative charge. The second factor explaining $31.7 \%$ of the total variance was found to have high positive load values of $\mathrm{Cr}$ and $\mathrm{Ni}$. In the study conducted by Kır \& Tumantozlu, (2012) on the change of heavy metals in water and sediment in Karacaören Dam Lake, the heavy metal analysis results showed that all metals deposited in sediment are in different amounts. It is stated that the results may be related to the sedimentation particles absorbing metals in water and deposition of high molecular weight metals.
In another study conducted in Bangladesh, Islam et al. (2015) tried to determine the heavy metal content of water and sediment samples taken from a river near the city and found that the elements were above the threshold value. The results show that the metal concentrations of the elements in the sediments decreased in the order $\mathrm{Cr}>\mathrm{Ni}>$ $\mathrm{Cu}>\mathrm{Pb}>\mathrm{As}>\mathrm{Cd}$.

The cluster analysis for sediment samples created two groups. The first group was found to have similarities between 100-750 $\mathrm{m}$ distance and the second group was similar to the sediment samples at $1000-10000 \mathrm{~m}$ distance. The first group is of an area with high pollution value, while the second group is of a low pollution area. According to a similar study conducted in Mongolia, $\mathrm{As}, \mathrm{Cu}$, $\mathrm{Hg}, \mathrm{Pb}$ and $\mathrm{Zn}$ contents of sediment samples taken from the river near a gold mine were measured and analyzed. In that study, it was found that heavy metal pollution decreased gradually depending on the distance to the gold mine and almost disappeared when it fell to the Zhaosu River away from the mining site (Gao, 2017).

When the heavy metal measurement results of soil and sediment samples were evaluated, the most important factor in the field was the existence of $\mathrm{Cu}, \mathrm{Pb}$ and $\mathrm{Zn}$ heavy metals according to the factor analysis. The cluster analysis confirmed that the contamination was higher at the points close to the source of pollution than that at the distant points. Bilge \& Çimrin (2013) examined the changes in $\mathrm{Pb}, \mathrm{Cd}, \mathrm{Ni}, \mathrm{Cr}$ and $\mathrm{Cu}$ concentrations in the soils near the Viransehir-Kiziltepe highway and observed that the heavy metal concentrations decreased as it was moved away from the highway.

The heavy metal analysis results of soil and sediment samples indicated that $\mathrm{Cu}, \mathrm{Mn}$, $\mathrm{Pb}, \mathrm{Zn}$ values are above the threshold values, especially in the areas close to the pollutant source. This leads to contamination of the soil, sediment and thus the streams around the mining site. Similar study by Christou et al. (2017) conducted heavy metal analyzes of soil and agricultural products taken at different distances between 0 and $2000 \mathrm{~m}$ around an abandoned mining site in Cyprus in 2017. They found that the heavy metal 
ratios increased as they approached the mining site and the heavy metals rates in agricultural products produced exceeded the threshold values. In another study by Xiao et al. (2017), heavy metal contents of soil, pulp and different agricultural products taken from the areas near the mining site were analyzed. It was observed that heavy metal values were high for all three criteria near the mining site. In the study conducted by Kankılıç (2019) based on the sediment samples taken from Kapulukaya Dam, the concentrations of $\mathrm{Al}, \mathrm{Fe}, \mathrm{As}, \mathrm{Cr}, \mathrm{Ni}, \mathrm{Pb}, \mathrm{Zn}$, $\mathrm{Cd}$ and $\mathrm{Hg}$ elements increased with (except $\mathrm{Hg}$ ) the average values of the three stations after the point where the waste water was released.

According to the results of soil reaction analysis, one-way analysis showed that there was a difference between $\mathrm{pH}$ values depending on the increase in distance. The statistical analysis confirms that the $\mathrm{pH}$ measurement values near the polluted area are low (i.e., that is acidic) and increase away from the source of pollution (i.e., the decrease of acidity). Such results show that there is a heavy metal pollution in the area. In a study conducted by Oseni Olalekan et al. (2014), the PH analysis and heavy metals of the soil samples taken from 5 different landfills were analyzed and the values of $\mathrm{Zn}$ and $\mathrm{Pb}$ were found to be higher than the threshold values, and as a result the $\mathrm{pH}$ values were found to be acidic.

According to the results of the study, the average values of heavy metal accumulation levels in soil were determined as; $\mathrm{Mn} ; 719$ $\mathrm{mg} / \mathrm{kg}, \mathrm{Cu} ; 337.8 \mathrm{mg} / \mathrm{kg}, \mathrm{Pb} ; 174.8 \mathrm{mg} / \mathrm{kg}$, $\mathrm{Zn} ; 157.5 \mathrm{mg} / \mathrm{kg} ; \mathrm{Ni} ; 15.5 \mathrm{mg} / \mathrm{kg}, \mathrm{Cr} ; 14.5$, the results show that the metal concentrations of the elements in the soil decreased in the order $\mathrm{Mn}>\mathrm{Cu}>\mathrm{Pb}>\mathrm{Zn}>\mathrm{Ni}>$. The metal concentrations of the elements in the sediments decreased in the order $\mathrm{Cr} ; 3850.1$ $\mathrm{mg} / \mathrm{kg} ; \mathrm{Pb} ; 2984.2 \mathrm{mg} / \mathrm{kg}, \mathrm{Zn} ; 1010.5 \mathrm{mg} /$ $\mathrm{kg}, \mathrm{Mn} ; 403.7 \mathrm{mg} / \mathrm{kg}, \mathrm{Ni} ; 13 \mathrm{mg} / \mathrm{kg}, \mathrm{Cr}$; $12.7 \mathrm{mg} / \mathrm{kg}$ and $\mathrm{Cu}>\mathrm{Pb}>\mathrm{Zn}>\mathrm{Mn}>\mathrm{Ni}>\mathrm{Cr}$. In conclusion, the heavy metal levels in both soil and the river sediments were remarkably high, but varied among sampling points. Our results suggest that special attention must be given to the issue of metal re-mobilization, because a large portion of metals in both soil and sediments are likely to release back into the water column.

The rehabilitation works of the mining enterprises should be carried out not only in the mining site but also in the nearby areas outside the mining site where the pollution is intense and the necessary legal measurements for this should be taken into consideration. In this context, in order to help remove heavy metals from the soil during the rehabilitation activities to be applied in the mining sites, it is suggested to investigate the phytoremediation techniques, defined as the removal of heavy metals from the plants, which are very successful and effective methods both economically and ecologically, and to use appropriate plant species in the rehabilitation areas. Furthermore, awareness activities about identifying the possible damages to the environment beforehand, taking necessary measures and minimizing the possible damages during the production process in an industrial field are essential.

\section{Acknowledgments}

This study was supported by Artvin Çoruh University's Scientific Research Project Unit (No: 2016.F10.02.07)

\section{References}

Ahmad, A. N. (2017). Kuzey Irak Topraklarında Endüstriden Kaynaklanan Ağır Metal Kirliliği, Yüksek Lisans Tezi, Yüzüncü Yıl Üniversitesi, Van.

Adagunodo, T. A., Sunmonu, L. A. \& Emetere, M. E. (2018). Heavy metals' data in soils for agricultural activities. Data in brief, 18, 18471855.

Akbulut, N. E. \& Tuncer, A. M. (2011). Accumulation of heavy metals with water quality parameters in Kizılırmak River Basin (Delice River) in Turkey. Environmental monitoring and assessment, 173(1-4), 387395.

Alp, M. T., Ozbay, O. \& Sungur, M. A. (2012). Determination of heavy metal levels in sediment and macroalgae (Ulva sp. and Enteromorpha sp.) on the Mersin coast. Ekoloji, 21(82), 47-55.

Anonymous. (2005). Federal Bureau of Statistics, Statistics Division, Government of Pakistan, Islamabad. Pakistan Statistics Year Book.

Bagheri H., Alinejad S. \& Bastami K. D. (2011). Heavy Metals (Co, Cr, Cd, Ni, Ph And Zn) İn 
Sediment Of Gorganrud River, Iran. Research, Journal of Environmental Toxicology, 5(2), 147-151.

Begum A., Ramaiah M., Harikrishna Khan İ. \& Veena K. (2009). Heavy Metal Pollution and Chemical Profile of Cauvery River Water. Ejournal of Chemistry, 6(1), 47-52.

Bilge, U., \& Çimrin, K. M. (2013). ViranşehirKızıltepe karayolu kenarındaki topraklarda motorlu taşıtlardan kaynaklanan ağır metal kirliliği. Journal of Agricultural Sciences, 323-329

Bilici, M. (2005). Van Yöresi Sanayi Sitesinde Çalışan İşçilerin Kan Serumlarında Bazı Elementler (Çinko, Krom, Kurşun, ve Kadmiyum) ile Bazı Karaciğer Enzimleri (ALT ve AST) Seviyesinin Tayini (Yüksek Lisans Tezi), Yüzüncü Yıl Üniversitesi, Fen Bilimleri Enstitüsü, Kimya Anabilim Dalı, Van.

Chapmann, N. D., Pratt, P. F. \& Parker, F. (1961). Methods of analysis for soils, plants and waters. University of California Division Agriculture and Natural Resources Sciences, Riverside.

Chehregani, A. \& Malayeri, B. E. (2007). Removal of heavy metals by native accumulator plants. International Journal of Agriculture and Biology, 9, 462-465.

Christou, A., Theologides, C. P., Costa, C., Kalavrouziotis, I. K. \& Varnavas, S. P. (2017). Assessment of toxic heavy metals concentrations in soils and wild and cultivated plant species in Limni abandoned copper mining site, Cyprus. Journal of Geochemical Exploration, 178, 16-22.

De Astudillo, L. R., Yen, I. C. \& Bekele, I. (2005). Heavy metals in sediments, mussels and oysters from Trinidad and Venezuela. Revista de biología tropical, 53(1), 41-53.

Duyar, A., 2019. Endüstriyel hava kirliliği toprak mikro eklembacaklılarının (Arthropoda) miktar ve çeşitliliğini etkiler mi?, Bartın Orman Fakültesi Dergisi, 2019, 21(3), 884892.

EPA-3052, (1996). U.S. Environmental Protection Agency, EPA-Method 3052, Microwave assisted acid digestion of siliceous and organically based matrices, U.S. Government Printing Office, Washington, DC.

G. Toth., T. Hermann., M. R. Da Silva. \& L. Montanarella. (2016). Heavy metals in agricultural soils of the European Union with implications for food safety, Environment International, 88, 299-309.

Gao, Z. (2017). Evaluation of heavy metal pollution and its ecological risk in one river reach of a gold mine in Inner Mongolia, Northern China. International Biodeterioration \& Biodegradation.

Gülçur, F. (1974). Toprağın Fiziksel ve Kimyasal Analiz Metodları, İ.Ü. Yayınları Yayın No:1970, Orman Fakültesi Yayın No:201, Kurtuluş Matbaası, İstanbul.

Gözdaşoğlu S., Çavdar A. O., Arcasoy A. \& Akar N. (1989). Serum copper and zinc levels and copper/zinc ratio in patients with head and neck cancer. Magnesium, 8, 77-86.

Jackson, W. A. (1967). Physiological effects of soil acidity. Soil acidity and liming, 12, 43124.

Kale, D. (2014). Aliağa (İzmir) Endüstri Bölgesinde Topraktaki Ağır Metal Kirliliğinin Manyetik Duyarlılık Ölçümleriyle Belirlenmesi, Yüksek Lisans Tezi, Dokuz Eylül, Üniversitesi, İzmir.

Kanat, Y. (2005). Ağır Asfalt İşlerinde Çalışan İşçilerin ve Kırsal Kesimde Yaşayan Kişilerin Kan Serumlarında Bazı Ağır Metal İyonları ile Bazı Spesifik Karaciğer Enzimleri ve Testesteron Hormonu Miktarlarının Tesbiti (Yüksek Lisans Tezi, Basılmış) Y.Y.Ü. Fen Bilimleri Enstitüsü Yayını. Van.

Kankılıç, G. B. Kapulukaya Barajı Aşağı Havza'sı Sediment Örneklerinde Ağır Metal Kirlilik Düzeylerinin Değerlendirilmesi (Kızılırmak, Kirıkkale). Bitlis Eren Üniversitesi Fen Bilimleri Dergisi, 8(3), 903913.

Khan, S., Hesham, A. \& Qiao, M. (2010). Effects of $\mathrm{Cd}$ and $\mathrm{Ph}$ on soil microbial community structure and activities. Environmental Science and Pollution Research, 17, 288-296.

Kir, I., \& Tumantozlu, H. (2012). Investigation of some heavy metal accumulation in water, sediment and carp (Cyprinus carpio) samples of Karacaoren-II Dam Lake. Ekoloji, 21(82), 65-70.

Knezevic M., Stankovic D., Krstic B., Nikolic M S. \& Dragica V. (2009). Concentrations of heavy metals in soil and leaves of plant species Paulownia elongata S.Y.Hu and Paulownia fortunei Hemsl. African Journal of Biotechnology, 8(20), 5422-5429.

Kohli GS., Bhargava A., Gocl II., Yadav S'PS., Saint AS., Singh GP. \& Lal II. (1989). Serum magnesium levels in patients with head and neck cancer. Magnesium, 8, 77-86.

Korkmaz, A. \& Kızılkaya, R. (1998). Çevresel toprak sorunları ve Gübrenin çevre kirliliğine katkısı. Ondokuz Mayıs Üniversitesi, Ziraat Fakültesi Dergisi. 13, 147-164.

Macdonald Dd., Ingersoll Cg., Berger Ta. (2000). Development and Evaluation of Consensusbased Sediment Quality Guidelines for 
Freshwater Ecosystems. Archives of Environmental Contamination Toxicology, 39, 20-31.

Okereafor, U., Makhatha, E., Mekuto, L. \& Mavumengwana, V. (2019). Dataset on assessment of pollution level of selected trace metals in farming area within the proximity of a gold mine dump, Ekuhurleni, South Africa. Data in brief, 26, 104473.

Olivares-Rieumont, S., De la Rosa, D., Lima, L., Graham, D. W., Katia, D., Borroto, J. \& Sánchez, J. (2005). Assessment of heavy metal levels in Almendares River sedimentsHavana City, Cuba., Water Research, 39(16), 3945-3953.

Oseni Olalekan, A., Taiwo Abayomi, G., Ijaola Taiwo, O. \& Yenusa Luqman, A. (2014). The Effects of $\mathrm{pH}$ On the Levels of Some Heavy Metals in Soil Samples of Five Dumpsites in Abeokuta and its Environs.

Özbolat, G. \& Tuli, A. (2016). Ağır Metal Toksisitesinin İnsan Sağlığına Etkileri. Arşiv Kaynak Tarama Dergisi, 25(4), 502-521.

Rauf A, Javed., M, Ubaidullah. \& M, Abdullah S. (2009). Assessment of Heavy Metals in Sediments of The River Ravi, Pakistan. International Journal of Agriculture and Biology 11, 197-200.

Sabiha-Javied, M.T., Tufai, M. \& Irfan, N. (2009). He4iavy metal pollution from phosphate rock used for the production of fertilizer in Pakistan. Microchemical Journal, 91, 94-99.

Seven, G. (2010). Meme, Baş boyun ve Mide Kanserli Hastalarda Radyoterapi Öncesi ve Sonrası İz Elementler ve Ağır Metal Düzeylerinin ( $\mathrm{Zn}, \mathrm{Cu}, \mathrm{Pb}, \mathrm{Cd}, \mathrm{Mn}, \mathrm{Mg}$ ve $\mathrm{Co}$ ) ve Bazı Biyokimyasal (Katalaz ve Karbonik anhidraz) Parametrelerin İncelenmesi, (Yüksek Lisans Tezi, Basılmamış), Yüzüncü Y1l Üniversitesi, Fen Bilimleri Enstitüsü, Kimya Anabilim Dalı, Van.

Shrestha, S., \& Kazama, F. (2007). Assessment of surface water quality using multivariate statistical techniques: A case study of the Fuji river basin, Japan. Environmental Modelling \& Software, 22(4), 464-475.

UNEP, (2013). Environmental risks and challenges of anthropogenic metals flows and cycles, in: E. van der Voet, R. Salminen, M. Eckelman, G. Mudd, T. Norgate, R. Hischier (Eds.), A Report of the Working Group on the Global Metal Flows to the International Resource Panel, 231.

Xiao, R., Wang, S., Li, R., Wang, J. J. \& Zhang, Z. (2017). Soil heavy metal contamination and health risks associated with artisanal gold mining in Tongguan, Shaanxi, China. Ecotoxicology and Environmental Safety, 141, $17-24$. 